Classification of the Animal Kingdom", and medical science by one on "The Nature and Treatment of Sclerosis", a process terminating in hardening and calcification in tissues and organs. The latter presents the subject largely from a metaphysical and homøopathic point of view, and cannot be accepted as representing modern medical conceptions. The metaphysical also looms large in "Alterations in the Earth's Surface", and so far as science is concerned, the articles can scarcely be accepted as representative of its modern aspects.

\section{New Garden Plants}

THE present generation of horticulturists is fortunate in the ever-increasing number of new contributions to garden beauty. Scientific hybridisation and selection have produced more pleasing shades of bloom, or enhanced symmetry of form from old favourites, whilst ardent botanists roam amongst the wilder parts of the world to find new grandeur for the rockery or herbaceous border. Plants from these sources which have stood the test of English cultivation are described ( $J$. Roy. Hort. Soc., November) by Dr. Fred Stoker, who writes on "Ericaceous Plants" and Mr. Ben Wells, who discusses herbaceous subjects. Both accounts are well illustrated with excellent half-tone plates, and give many practical details.

\section{Memorandum on Pneumonia}

PNEUMONTA, as a cause of national mortality, has long been a matter of concern to public health authorities. In 1934, for example, this disease was responsible for 28,623 deaths in England and Wales, and in times of influenza prevalence the martality may reach a much higher figure. The Ministry of Health has, therefore, issued a Memorandum (Memo. 189 Med.) with covering circular (No. 1499) on the subject for the use of public health authorities, in which the classification and bacteriology, its prophylaxis and the general administrative measures applicable, are dealt with (H.M. Stationery Office. ld. net).

\section{Physical Society's Exhibition}

THE twenty-sixth annual exhibition of scientific instruments and apparatus arranged by the Physical Society opens at the Imperial College of Science and Technology on January 7. The times of admission are 3-6 and 7-10 p.m. (January 7), 2-4, 4-6 and 7-10 p.m. (January 8) and 3-6 and 7-10 p.m. (January 9). A descriptive catalogue of the exhibits can be obtained from the Exhibition Secretary, Physical Society, I Lowther Gardens, Exhibition Road, London, S.W.7 (1s. post paid), to whom applications for tickets of admission should also be addressed.

\section{Indian Science Congress Association}

THE twenty-third annual meeting of the Indian Science Congress Association is being held on January 2-8 at Indore, under the presidency of Rai Sir Upendranath Brahmachari Bahadur. The presidents of sections are as follow: (1) Mathematics and Physics: Dr. T. Royds, director of the Kodaikanal Observatory ; (2) Chemistry: Dr. P. C. Guha, professor of organie chemistry, Indian Institute of Science, Bangalore; (3) Geology and Geography: B. Rama Rao, officiating director of geology, Mysore Geological Department, Bangalore ; (4) Botany: Dr. S. R. Bose, professor of botany, Carmichael Medical College, Calcutta ; (5) Zoology: Dr. H. K. Mookerjee, University professor and head of the Department of Zoology, University of Calcutta ; (6) Anthropology: H. C. Chakladar, lecturer in anthropology, University of Calcutta; (7) Agriculture: A. K. Yagna Narayan Aiyer, formerly director of agriculture, Sankarapuram, Bangalore ; (8) Medical and Veterinary Research: Lieut.-Col. H. E. Shortt, director of the King Institute, Guindy, Madras; (9) Physiology: Dr. W. Burridge, professor of physiology, University of Lucknow ; (10) Psychology : J. M. Sen, inspector of schools, Presidency Division, Bengal.

\section{Recent Meteors and Fireballs}

The Meteoric Display of November 21. A letter has been received from Mohd. A. R. Khan, whose wireless message was published in NATURE of November 30, p. 867, as follows: "I observed over one hundred meteors between $6 \mathrm{~h} .50 \mathrm{~m}$. and $7 \mathrm{~h} .10 \mathrm{~m}$. G.M.T. on November 21, of which several were of first magnitude with long trails. Eleven more were observed in the next 20 minutes. The sky was rather hazy. Perhaps the richest part of the shower occurred somewhat earlier, before I began observation". The possible return of this shower should be looked for by meteor observers in future yoars.

A great Detonating Fireball. On November 25, at $0 \mathrm{~h} .20 \mathrm{~m}$. U.T., a meteor which announced its arrival with a 'blinding glare of light' was observed in south-west England by many people. At Bridgwater there was a loud explosion after the disappear. ance of the fireball, "followed by a rumbling noise resembling thunder, lasting for about a minute". Heavy detonations were also heard at Weston-super. Mare and Bristol. Mr. A. King, of 53 Victoria Road, Ashby, Scunthorpe, Lincs, has received some ten accounts, but they are mostly so vague (and in some cases contradictory) that a definitive real path cannot be computed. All that can be said in this respect is that the object passed over the district between Bridgwater and Bristol at a low height.

Daylight Firebali. On December 3, at 1lh. 30m. U.T., an observer in Bradford saw a meteor with a long tail shoot across the eastern sky. This must have been a very fine fireball. Observations of the fireball should be sent to Mr. King.

\section{Announcements}

THe Catherine Wolfe Bruce Gold Medal for 1936 of the Astronomical Society of the Pacific has been awarded to Prof. A. O. Leuschner, professor of astronomy and director of the Students' Observatory in the University of California, for distinguished services in astronomy. Prof. Leuschner is an authority on the determination of the orbits of planets. 